\title{
THE INTERNATIONAL CONTEXT OF MOROCCO'S STALLED DEMOCRATISATION
}

\author{
Francesco Cavatorta \\ School of Law and Government \\ Dublin City University \\ Glasnevin, Dublin 9 \\ Ireland \\ E-mail: Francesco.Cavatorta@dcu.ie \\ Phone: +353-1-700 7858
}




\section{$\underline{\text { Introduction }}$}

The literature on transitions to democracy is very large and can count both on theoretical works and a number of case-studies that can be drawn upon to understand one of the most relevant political events in the life of any country: regime change. In theoretical terms, the literature has seen the emergence of interpretative schools that highlight the main tenets of democratisation. ${ }^{1}$ When it comes to case studies, processes of democratisation have been examined across continents, in diverse cultural contexts and with regard to different systems of authoritarian government. The vast majority of these studies have been carried out within the confines of comparative politics and according to Grugel 'the home of democratisation studies has traditionally been comparative politics.' This means that, with some notable exceptions, the literature has suffered from a lack of engagement with international relations. The result has been a marginalisation of international variables as key explanatory factors in favour of domestic variables. This is also the case in the works of scholars who first introduced the international dimension such as Huntington ${ }^{3}$ and Whitehead, ${ }^{4}$ although the latter seems to have recently revised his position. Thus, the process and the outcome of a founding moment in the life of a country have been explained as if occurring in a vacuum.

More recently, there have been efforts made to deal with this gap and there have been calls to bridge comparative and international politics when examining regime change. ${ }^{5}$ This paper follows this path and presents a theoretical discussion that includes international variables into the study of regime change and empirically examines the case of Morocco.

Before looking at the theoretical issues, it is necessary to highlight the reasons behind the choice of Morocco and tackle the methodological difficulties that exist when selecting only one case. There are three reasons why the choice of Morocco is valid. First of all, the comparative literature on transitions tended to neglect the Middle East and North Africa (MENA). For instance, in his wide-ranging study, Huntington did not mention the MENA at all in spite of the liberalising trends that the region experienced in the 1980s and 1990s. Secondly, Morocco saw its high hopes dashed and today it is assigned to the category of liberalised autocracies. These are countries 'tempering authoritarianism with pluralism' ${ }^{6}$ and 'with their ultimate reliance on the supreme 
authority of the monarch or the president, [they] provide a kind of virtual democracy. ${ }^{7}$ Thus, explaining a failure can contribute to the understanding of the process of democratisation just as a successful case can. ${ }^{8}$ Transitions to democracy can fail, or at least stagnate, and if international factors are part of the explanation, it is important to highlight their influence. Finally, Morocco can be considered a paradigmatic case in terms of the relationship that exists between political liberalisation, Islamic opposition and international acceptance of such movements. The rise of Islamist parties during transitions in the Arab world has important repercussions for the West-dominated international community both at policy-making and normative levels.

The selection of one case study to make general inferences about a theoretical framework is considered problematic. ${ }^{9}$ This study accepts that there are important limitations to the examination of only one case, but the in-depth investigation of Morocco can highlight trends that can be generalised to other similar cases and there is today a substantial scholarship that defends a methodology based on a single case study. ${ }^{10}$

\section{The International Dimension: a Framework of Analysis}

For a long time, the study of transitions assumed that 'democratisation [was] a domestic affair par excellence. ${ }^{11}$ In summarising the spirit of the literature, Yilmaz noted: 'democratic transition has been one particular field of study in comparative politics where the dismissal of international factors has been more pronounced than in other fields. ${ }^{, 12}$ There are two fundamental reasons that explain why the domestic focus is so pronounced to the detriment of international variables.

On theoretical grounds, it is difficult to have a shared definition of what constitutes the international context. Given these definitional difficulties, it is problematic to link international variables to domestic change, as there is no agreement to what the external environment actually is and how it might operate. This does not mean that the international context is not somehow incorporated in the analysis. Most scholars cannot ignore the external environment, but they treat it as having only a very marginal effect on the process of transition. Furthermore, the poor theoretical conception of the external environment leads inevitably to think of international variables in structural terms. This 
marginalises external active and specific policies that international actors may take and that may have an impact on transitions through their linkages with the domestic actors.

On practical grounds, it is particularly difficult to find the evidence that would point to a causal mechanism at work between international factors and domestic change. The combined effect of theoretical and practical difficulties contributes to the unwillingness of transitology to engage with international variables.

In spite of such difficulties, it is becoming increasingly awkward to exclude international factors from the analysis of regime change. ${ }^{13}$ A number of scholars attempted to incorporate the international context in their studies of democratisation, as it seems beyond doubt that major shifts in the distribution of power in the international system and global political and economic trends contributed to a number of democratisations. ${ }^{14}$ However, they ultimately concluded that domestic factors still prevail when it comes to explaining the pattern of development of a transition. For the most part, scholars such as Whitehead and Pridham did not take on board definitions and theoretical tools from other traditions and remained faithful to the literature on comparative politics, which neatly separates external and internal factors. The impact of their attempts should not be dismissed, as it was the first step to encourage others to pursue the examination of the international dimension, but it should also be recognised that they do not conceive of the centrality of international factors.

Whitehead, for instance, argues that the external dimension has a 'limited' impact during the consolidation period, but not before then. For example, the role played by the European Union during the Spanish, Portuguese and Greek transitions is that of a 'facilitator of democracy' thanks to the carrot of membership that is on offer. In his analysis, the EU does not directly exercise policy-making influence on the domestic bargaining process between ruling and opposition elites, which characterises the development of transitions in a complex game to set up new political arrangements. For his part, Huntington argues that there are powerful international triggers to transitions, but then proceeds to explain the course of regime change only through the same domestic bargaining process. All this points in the direction of seemingly 'fixed' resources and 'objectives' that the domestic actors have when they play the 'game' of transition and excludes the possibility that external actors may actually modify such resources and 
objectives throughout the game itself therefore altering the outcome. Domestic actors react to 'domestic events' during a transition in order to improve their position, but just as they adapt to changed internal conditions, they may also be very aware that they need to adapt to external actions. At the same time, external actors can change their direct policies according to what the domestic 'game' generates in terms of political dynamics. A rather more complex game involving both the external and the internal is a more plausible interpretative framework.

In addition, both Huntington and Whitehead make a very limited use of the 'international' and confine it to one specific phase of the process of transition (although they disagree on the phase to focus on), but the assumption could be made that if external factors have an impact, they do so during all the phases of the transition.

Crucially, a number of recent studies attempted to capture the centrality of the international dimension through the contamination of comparative politics with international relations. Yilmaz has put forth a prominent study developing an open model of democratic change. ${ }^{15}$ Also, Gillepsie and Youngs focus their attention on the role played by the European Union in the Mediterranean ${ }^{16}$ and Cavatorta examines the role of external variables in the failed democratisation of Algeria. ${ }^{17}$ These studies attempt to look at transitions in a more encompassing manner and refuse to a large extent to assume that such important processes can take place in a virtual vacuum.

However, within this limited literature, it emerges a strong bias towards structural approaches. For instance, Hamanreh's approach to 'the global wave of political liberalisation $^{, 18}$ affecting the region centres only on structural economics. In his explanation, it is the capitalist international system that drives domestic changes and in the late 1980s this meant that structural adjustment programs destined to introduce market oriented reforms were an agent of democratisation in the Arab world. While this is an important point, it fails to address the politics of the international system and through its structuralism makes transitions seem predetermined in terms of outcome. In such a model, there is very little room to manoeuvre for the domestic actors, as they are conceived as being completely at the mercy of externally generated constraints. Yilmaz's contribution is possibly more effective, although still too 'structural.' It is a valuable attempt to make sense of the international dimension of transition to 
democracy through the use of international relations theory and through the connection between domestic actors and their external environment in terms of cost and benefit analysis for the actions they undertake and the strategies they pursue. In addition, through the use of Wallerstein's theory, Yilmaz highlights how semi-peripheral states 'have been rapidly losing their control over the movements of people, capital, and information in and out of their boundaries. ${ }^{19}$ However, there are two points of criticism. First of all, it seems that Yilmaz's contribution is limited to the consolidation phase of the transition and this poses a 'timing' problem. If international factors were active at the end of a transition, why would they be inactive during the other phases? The second criticism that can be laid at Yilmaz's door is his reliance on world system theory, which is not an entirely convincing theory, as Cox argues. ${ }^{20}$

In order to avoid such pitfalls, the international context should be defined according to a mix of structure and agency and could be conceived of three different types of pressure that countries experience. These are:

- Structural pressures generated at international level, which lead countries in the system to conform to specific political and economic requirements in order to fit into a West-dominated system.

- Ad hoc policies adopted by the leading nation-states in the system, which aim at influencing the domestic distribution of resources among actors to achieve their most preferred outcome in line with their national interest.

- External shocks that condition the domestic bargaining game. These shocks take place outside the country under examination and cannot be controlled by domestic actors.

In this framework of understanding, structuralism is tempered by both international and domestic agency because explanations of complex political phenomena are seldom 'mono-causal' and often see a dynamic relationship between agency and structure. This is also the crucial point where some concepts imported from the classic realist school of international relations could be useful and where the previous literature's emphasis on structuralism should be tempered with the introduction of the 'agency' of specific actors. The acceptance of some realist concepts such as power and interest does not mean that the all theoretical claims realism makes should be taken on board, but it simply indicates 
that the recent excessive focus on liberalism (with its pro-democracy stances) and on normative foreign policies might be misplaced. States and other international actors still take action according to their interests and the effects these actions have are still dependent on power. For instance, policies aimed at exporting democracy are not primarily about the establishment of democracy per se, but about security. Democracy is not exported because of its inherent normative superiority to other political systems, but because it is seen as the best means to achieve stability and security. From this, it follows that the possibility of the emergence of a 'bad democracy' (i.e. an Islamist party in power through democratic procedures) is a threat to the pursuit of democracy and therefore such an outcome should be avoided, if possible, in favour of 'good authoritarianism.' This fits in quite well with the realist emphasis on attaining specific 'goals' for the benefit of one's state with the consequent marginalisation of moral behaviour.

The innovation of this framework of understanding rests on the introduction of two analytical dimensions, which countries should be categorised on. These dimensions 'frame' the three types of pressures outlined above. Regarding the first dimension, there is the position of a country in the international economic system. In this context, the contribution of those who highlight the relevance of structural approaches should be recognised, but, at the same time, the international economic system should be overestimated as an explanatory variable. Thus, the international economic dimension is a relevant tool of analysis because of the type of international pressure that can be applied by a range of actors (i.e. conditionality). In a highly interdependent economic system, it is very difficult for any country to be isolated from the global economy and be able to pursue policies in tension with mainstream economic wisdom without suffering consequences, but such mainstream vision is the product of the stronger actors in the system, who promote it to benefit from its implementation. This is in line with the precepts of classical realism, which postulates that leading countries will implement the policies that in the short-term ensure the pursuit of their 'interests' and guarantee their security. Once the economic position of a country is determined within the system and how changes there might affect the powerful states active in the region, it becomes clearer if it is more or less prone to feel changes at the international level. It is for this reason that any effective theoretical framework that wants to incorporate the international 
dimension has to identify the position of the country under examination in economic terms.

On the second dimension, there is the position of a country in the political international system. In this case as well, realism can become a contingent useful tool of analysis because it allows the ranking countries in terms of their relevance for the leading actors in the system. ${ }^{21}$ Some nation-states are extremely important for their geo-strategic location and regime change in these states tends to have more relevant repercussions externally than if it were taking place in states at the margins of the system. It is for this reason that external actors acquire an interest in the outcome and attempt to influence how regime change proceeds. Thus, an analysis of the geo-political and geo-strategic surroundings of a country is the key to understanding how external actors may be involved, directly or indirectly, in the calculations and strategies of domestic actors because of the spill-over effects on the region. Radical change has profound consequences internationally, as a new government in power may behave very differently from the previous one and therefore impinging on the interests of its neighbours and of a range of international actors (i.e. Iran in 1979). This geo-political thinking is not limited to nation-states, but is a feature of non-state actors as well. With regards to this, it is important to re-introduce the notion of 'pivotal states.' A pivotal state is defined as 'a hot spot that could not only determine the fate of its region but also affect international stability. ${ }^{22}$ The concept is used to denote the importance of certain nation-states across the globe with respect to the dominant actors in the system and their interests. Dramatic changes within what powerful international actors consider a pivotal state are therefore monitored with much greater attention and attempts are made to influence the outcome of domestic struggles for control of the government. It follows that there are nation-states that are more important than others for their potential capacity to affect regional and international stability. In the case under examination the United States and the European Union certainly see the countries in the region as pivotal in their security strategy and a number of non-state actors are equally concerned with such developments, leading them to attempt to modify the distribution of resources among domestic actors.

These two dimensions are only useful if some a priori assumptions are clarified and accepted. First of all, it is necessary to emphasise that, short of military invasion, it is 
the domestic actors who are formally in charge of the transitional game. It is up to the different factions within the ruling elites and within the opposition to play the game out, as they try to implement their strategies to arrive at their most preferred outcome. It follows that the role of international factors should be analysed in this context. However, this does not make them less central to explanation. In fact, such external variables can have a significant impact by altering the distribution of power and resources (through material inducements or disincentives or through ideological legitimacy) of the domestic actors, which in turn has an effect on how they will act. ${ }^{23}$

Secondly, it is assumed that processes of regime change are mostly pathdependent and that therefore it is imperative to analyse actors and their actions informed by strategies and objectives. This does not mean that structural approaches are not useful, as they provide the necessary context within which such actions take place. The levels of socio-economic development or structural economic and political transformations play a certain role, but structural explanations run the risk of predetermining outcomes, which instead are largely dependent on decision-making. This is the reason why the focus is here on agency and less on structure and follows the line of inquiry suggested by Quandt in his work on Algeria. ${ }^{24}$

Thirdly, it is fundamental to temper the realist assumption about the role of nation states and their centrality in international politics. While powerful states in particular remain the most important actors in the system, there are multiple international actors participating to the transition game and they influence domestic societies and actors at different levels and in different manners. It is therefore important to analyse the role that international financial institutions, multinationals and transnational bodies all play.

Finally, it is important to establish the normative value and meaning of democracy in the literature on transitions. This aspect deserves a longer discussion because it is a key element in understanding transitions in light of the international dimension. Far from being the essentially contested concept it is in political theory, democracy is a well-established model in transitology and, even more importantly, it is also an objective model for policy-makers. One of the main tenets of transitology is indeed the coincidence existing between democracy and the specific type of it that is western-style liberal democracy. This, not coincidentally, happens to be the mode of 
government of the most powerful states in the international system and the model preferred by international financial institutions. When a process of political liberalisation begins in any given country, the population within it determines the validity of their democratic choice only up to a point. In fact, full democratic legitimacy and credentials depend on final analysis on a process of external recognition. The outside world judges if the process of regime change can be qualified as having been successful or as having failed. The problem with this is that the only accepted version of successful democracy is a western one. This is exemplified by Schmitter and Karl's work on the essential features of democracy. ${ }^{25}$ While highlighting that democracy does not require the same set of institutions across the board, their definition is clearly minimal and coincides with the procedural version. This is not per se negative; it simply confirms that any process of regime change that is attempting to arrive at a democratic society has a very well established internationally sanctioned blueprint.

While not being necessarily a negative development, it is nevertheless problematic. First of all, it pre-empts certain policies or institutional solutions from being adopted thereby restricting the options available to domestic actors when it comes to political, economic, legal and social arrangements. Secondly, there is the problem of cultural adaptation, which is particularly acute in the Muslim world where large Islamic movements tend to be seen as enemies of democracy by definition. ${ }^{26}$ This in turn influences external policies towards them and towards the other domestic actors. For instance, if policy-makers cannot conceive of an Islamic democracy, they will be unable to accept a process of transition, which legitimises Islamic parties. Finally, there exists the problem of pigeonholing the new democracies into a pre-conceived role, which serves the dominant actors in the system.

To summarise, it is the contention of this study that international factors play a central role in processes of regime change by affecting the cost and benefit analysis of domestic actors and by restricting the options available to them through the normative value attached to the meaning of democracy, which has a considerable external component. It is also the contention of this paper that these international variables have an impact throughout the whole process of transition and they are not simply limited to one of the phases of it. Through the use of two different dimensions and their 
interactions, it is possible to have a theoretical framework that can be useful guide to explore specific processes of regime change. In this context, it is useful to emphasise that the structural approaches used so far are not quite satisfactory because they limit the 'definition' of international context and seem to predetermine the outcome of regime change. This is not really the case because of the role of agency. Specific ad hoc policies can radically modify the domestic actors' structure of incentives and therefore an examination of leaders' actions undertaken according to Machiavellian 'situation-bound knowledge' is necessary. ${ }^{27}$ A more dynamic model that analyses internal-external linkages is potentially more useful. Also, it is important to re-evaluate the recent notions that the international environment does not operate any longer according to realism. There are certainly weaknesses in realism), but this should not obscure the fact that much of international politics is still played out according to notions of power, promotion of interests, security guarantees and interferences from centres of power in the affairs of weaker actors. Policies of democracy promotion should be seen in this light.

The next section will analyse the case of the Moroccan transition according to some of the hypotheses that the theoretical framework provide. In order for the framework to be considered useful and having some explanatory power, three tasks should be fulfilled and evidence should be found for these claims. First of all, the initial decision to open up the political system should be linked to both international structural changes and ad hoc policies implemented by external actors and should not simply be attributed to an autonomous domestic decision. Secondly, there should be evidence that the democratisation process developed with the central contribution of external factors, which changed the incentive structure of the domestic actors playing the game. Finally, given that the Moroccan transition is ultimately stalled, it should be investigated whether external factors contributed to this or not.

\section{Morocco's stalled democratisation: 1983-2004}

Since independence, Morocco has had 'a political system based on authoritarian pluralism. ${ }^{28}$ This should not obscure the fact that the country has been for a long time 'an authoritarian state that kept people in line by intimidation and abuse. ${ }^{29}$ 
By keeping in mind the two dimensions outlined in the previous section, we can have a better picture of Morocco's international position. From an economic point of view, the country has been integrated into the international economy for most of its postindependence existence by virtue of its links to the West. The absence of vast amounts of natural resources to rely on and the presence of a large agricultural sector meant that strategies of development were state-led, but they were also favourable to some sort of a market economy. In geo-strategic terms, the country always had substantial importance for the West, as it was one of its key allies in the region during the Cold War. Its strategic location combined with the prestige of the monarchy made Morocco a key state, whose domestic political developments had important repercussions. The relevance of Morocco did not disappear after the end of the Cold War. If anything, its relevance for American and European interests in the area increased due to the necessity of reliable partners in a volatile region. To this day, 'Morocco is generally well respected by world powers as a stable constitutional monarchy.... and an Islamic voice of moderation. ${ }^{30}$ In addition, the Kingdom has been important to the US for its friendly relations with Israel. ${ }^{31}$ Morocco made a number of tentative moves towards the establishment of democratic governance and it is therefore quite difficult to point to moments in time that could be identified as the beginning and the end of the transition. However, there are events that can be used as a departure and an endpoint of the Moroccan democratic experiment for the purposes of analysis. The choice is somewhat arbitrary, but a turning point could be identified with the arrival of the World Bank and the International Monetary Fund on the Moroccan scene in the early 1980s. ${ }^{32}$

The intervention of international actors in the key area of economic policymaking seemed to be a signal of further changes to come and the country experienced an easing of press censorship, the release of some political figures from opposition parties to participate to local elections and the call for new parliamentary elections. These were indeed held in September 1984 and the Socialist Party (a true opposition movement at the time) fared rather well. Moutadayene argues: 'during this period, the political system was greatly shaken, which added to and certainly culminated in the acceleration of democratisation. ${ }^{33}$ This does not necessarily indicate that Morocco was undergoing a serious political and institutional shake-up and that the period was devoid of 
contradictory actions, but it signalled that increased engagement with the international community could have political repercussions. The high point in this long transition was reached in 1997/1998, when King Hassan II launched his alternance initiative. Following the relatively free and fair parliamentary elections of 1997, parties that had been previously in opposition formed a new government in 1998. The King delegated some real powers to this new government and 'by inviting opposition groups into power, one of the key principles of liberal democracy - the rotation of political power between groups through elections - ha[d] been applied. ${ }^{34}$ Soon after launching the alternance, King Hassan II died and his son Mohammed VI succeeded him. His initial steps were 'framed within the project of transition designed by his father. ${ }^{35}$ The new King demonstrated a willingness to accelerate the process of democratisation by firing the powerful Minister of Interior and by 'launching campaigns against illiteracy and poverty [which] earned him the name King of the Poor. ${ }^{36}$

Despite the length of the process, democratisation failed to take hold and the past few years have seen a return to authoritarianism. The 2002 parliamentary elections were far from being free and fair and saw the renewed exclusion 'of a peaceful movement expressing authentic opposition, which reflects the political aspirations of the masses' 37 (the radical Islamic association Al-Adl Wal-Ihsane led by Sheikh Yassine). Finally, following the terror attacks in the United States and the Casablanca bombings of May 2003, the royal court reintroduced special dispositions restricting civil and political rights. While the country has not reverted back to full authoritarianism, "it is likely that Morocco is no closer today to a decisive democratic breakthrough than it was four decades ago. ${ }^{38}$ Democratisation has stalled.

If we take the early 1980s as the beginning of a new phase in Morocco's political life as Maghraoui suggests, it emerges that on of the key factors triggering such a choice was the economic crisis the country experienced. The severity of the crisis led to bread riots quelled by the security forces, but repression was not the only answer and the king introduced a small degree of liberalisation. It is interesting to note at this stage that Huntington had identified the world economic crisis of the early 1980s as one of the factors triggering moves towards both economic and political liberalisation across the globe. It seems that Morocco was no exception to the trend. According to Moutadayene 
'the economy ...underwent a structural crisis which resulted in a crucial drop in GDP, deterioration of monetary and financial balances, increase in unemployment and a fall in purchasing power. ${ }^{39}$ If the hypothesis of the relevance of international factors in initiating the process of liberalisation is to be confirmed, there should be evidence that the economic crisis was due to external factors and that the domestic elites responded to such pressures through political openings.

Regarding the origins of the economic crisis, there is agreement that 'the country was severely affected by the recession in the world economy. ${ }^{40}$ The severity of the recession hit Morocco hard, particularly because it came at a time of high external debt. The recession compounded some of Morocco's structural economic problems, although the Moroccan economy had fared quite well during the 1960s and 1970s. Precisely because the economy had been doing quite well, the impact of the 'external' on the 'internal' is significant. Thus, it can be argued that the international economic crisis had a considerable impact in the collapse of the economy, even if the country was doing well until then. In addition, the role of the worldwide debt crisis seems to confirm the fact that international variables beyond the control of peripheral countries have a substantial impact on their domestic policy choices. The crisis forced the King to call on the services of the International Monetary Fund (IMF) and the World Bank (WB), which supervised a far-reaching program of economic reforms. Layachi points out that 'Morocco was the first country in North Africa to engage in structural adjustment (SAPs) ${ }^{41}$ and while aggressive liberalisation was successful in terms of macro-economic indicators, it did not improve the lot of most people. ${ }^{42}$ The decision to involve international financial institutions in rescuing the economy was far from being a fully autonomous decision. In fact, it was a decision almost dictated to the King by the international environment. As Najem argues, a new development paradigm for the Third World had established itself, 'which stressed economic liberalisation, especially free trade and privatisation as asserted by theorists and policy-makers. ${ }^{43}$ It would seem that turning to the IMF and the World Bank was the only strategy available to Hassan II to salvage the economy and that the resulting social problems due to the implementation of SAPs were countered with political openings. 
While it is not particularly problematic to link the Moroccan economic crisis with the world recession and to link market-oriented reforms with the work of international financial institutions, the causal mechanism between decision-making in the economic and political sphere is admittedly tenuous. What seems to emerge from the evidence is that the decision to open up the political system was entirely domestic and was based on the objective of regaining legitimacy and pre-empting tougher opposition. It is clear that external state and non-state actors did not really put any political pressure at the time on Hassan II to embark on political change. The IMF and the WB, unlike today, were not concerned with the political changes that should accompany economic reforms. For the reforms to work, transparency and accountability would have been necessary, but these actors refrained at the time from intervening in the political sphere. On their part, Morocco's democratic allies, the United States and France, were untroubled by Morocco's authoritarianism and democracy-promotion had yet to become a key foreign policy objective. What mattered at the time was regional stability and, in turn, the "state and the regime benefited to a great extent from Morocco's transnational and international engagements. ${ }^{44}$ Thus, there is really no evidence to suggest that pressure to reform the political system was applied and the role of international factors is limited to the triggering of the economic crisis. The abstention of key actors from promoting reforms points in the direction of the relevance of 'agency' in processes of transition.

Different conclusions can instead be drawn from the analysis of the period of democratisation that characterised the 1990s and from the failure of consolidation. The hypothesis is that during that time, both structural and actor-led external pressures had a considerable impact on the incentive structure of all domestic actors.

Before proceeding with the analysis it is however important to identify the three main domestic actors involved. The most important one is the King. The other two actors are the so-called democratic parties and the Islamist movements. This differentiation is rather simplistic because it assumes that Islamist groups are not democratic and it is also an instrumental differentiation in the sense that it seems to legitimise anti-democratic behaviour when it is directed at Islamist movements, but it is a common one particularly at policy-making level These three groupings have been affected to varying degrees by the external environment. 
When it comes to the monarchy, it emerges that the external pressures to continue on the path of democratisation have been rather weak and, while some encouragement came from Western allies particularly at the end of the Cold War, ${ }^{45}$ pressure to reform was never strong. No specific direct policy was devised to increase the costs of authoritarian rule from the two main sponsors of the country: Frances and the United States. Only the European Union attempted to encourage political reform by linking it to economic benefits for the Kingdom, but the policy has been contradictory and inconsistent.

The reluctance of external actors to seriously promote democracy can be seen in the following examples. When it comes to France, uncritical support for the monarchy has been the basis of French-Moroccan relations since independence. All French presidents, irrespective of their ideological background, co-operated very strictly with the Moroccan monarchs. French aid to Morocco is very significant and it represents the largest foreign contribution to the Kingdom (1.4 billion francs for 1998 only). In addition France is the 'primary' lender of funds and also the largest donor when it comes to EU funding. ${ }^{46}$ Such a financial effort from Paris does not include measures of debt cancellation that are periodically applied. Very little conditionality is applied to promote real institutional changes. ${ }^{47}$ All this points in the direction of a very 'realist' French foreign policy based on the assumption that stability in the region can be achieved through support for the monarchy. The 1994 La Baule initiative, when Mitterrand stated that French aid would be linked to democratisation, seemed to have an impact on Hassan II, but only in the short term, as France quickly demonstrated that 'cosmetic' changes would be sufficient to obtain French funds. The fear of the rise of political Islam is uppermost in Paris and support for the monarch never really wavered in the face of such a 'threat.'

When it comes to the EU, expectations of true normative behaviour have also been misplaced with respect to the Maghreb. By the mid 1990s, the European Union had begun to pay much closer attention to the southern bank of the Mediterranean and it launched the Euro-Mediterranean partnership in 1995 as a multilateral framework to deal with economic, political and social issues in the area. The Commission had identified political and economic reforms in the countries involved as the two priorities the 
partnership would tackle. This relationship should have been centred on the promotion of democracy, but EU security considerations in relation to the Maghreb are generally of a much more diffuse and socio-economic nature. Romeo affirms that 'they arise overwhelmingly from the issues of migration and Islamic revival ${ }^{48}$ and Youngs details these concerns as well. ${ }^{49}$ To this, it should be added that economic liberalisation took precedence over democratic political reforms. Thus, even the EU refrained from seriously pressurising the Moroccan government into implementing real democratic changes and seems to be satisfied by façade democratic gestures destined for the international public opinion. The other Mediterranean members of EU have also strengthened their links with Morocco (even at military level), leaving issues of democracy-promotion aside. Spain has been particularly active in this respect. ${ }^{50}$

For its part, the United States always supported the Kingdom. This is exemplified in the United Nations where the US used their influence to have former US Secretary of State James Baker appointed to solve the issue of the Moroccan occupation of Western Sahara. Baker has drawn up a plan that seems to legitimise Moroccan claims to Western Sahara in opposition to the rest of the international community. In sum, dependence on foreign loans and aid could lead Morocco to face enormous issues of 'conditionality' from the outside, but external actors do not use this potential tool of pressure in a coherent manner. Also, all leading external actors guarantee political legitimacy because 'for its principal allies and economic partners [US, EU and France], Morocco seems to be an example that needs to be followed [by other countries in the region]. ${ }^{, 51}$

The only type of external pressures on the King to pursue a policy of gradual democratisation can be labelled as second order pressures, as they are quite diffuse. The end of the Cold War represented a watershed in ideological terms: socialism collapsed and the values of the West had won. Accordingly, most authoritarian countries felt compelled to adapt their domestic political and economic institutions to the winning values of democracy and liberalism to profit from the new-look international system. Even countries that had been in the Western camp and whose authoritarianism had been tolerated felt that changes needed to be introduced to satisfy the needs of the Westdominated international community. It follows that Hassan II needed to revise the institutional make-up of the country. Other second-order pressures came from what can 
be termed the global civil society, which was very much concerned with issues of human rights abuses. An example of such influence has been the publication of the book Notre Ami Le Roi, which highlighted the Kingdom's brutal practices in relation to political opposition and human rights. ${ }^{52}$ The problem with these types of pressures is that they generate short-time indignation and short-time reactions, but fail in being successful in altering government policy in the longer term if they are not accompanied by the weight of state's diplomacy. Again, the relevance of realism should be emphasised.

While the end of the Cold War and the collapse of the socialist ideology did not dramatically change the King's structure of incentives, they had a much more profound impact on the secular opposition parties. The popular Socialist Party in particular could not rely any longer on any ideological legitimacy conferred by socialism. Furthermore, the lack of interest in real democratisation on the part of powerful international actors meant that such secular parties found themselves forced into accepting the alternance offered by Hassan II if they wanted any saying at all in the running of the country. Their effectiveness in government is however severely limited due to the tight control the King exercises on key governmental functions and due to the lack of alternative economic policies to the ones dictated by international financial institutions. The very poor socioeconomic conditions have given rise to strong Islamist movements and both the King and the secular opposition parties are afraid of their emergence and therefore adopt authoritarian measures to deal with them. This is quite paradoxical, as many members of the secular parties were in the past victims of similar abusive policies. Aboubakr Jamai argues that the entire political experience of the alternance is a failure precisely because 'what the left denounced and wanted to reform when in opposition is precisely what they fear reforming now that they are in government. ${ }^{, 53}$

\section{Political Islamism in Morocco}

The lax attitude of the international community regarding Moroccan authoritarian pluralism is today explained by the nature of the real Moroccan opposition. The effects of the international context are particularly intense when it comes to examine the opposition Islamist movements. Eheteshami notes that the international environment for the interaction between Islam and democracy is a particularly important fact. ${ }^{54}$ 
Currently, there are three strands of Islamism in the country. ${ }^{55}$ First of all, there is a legally recognised political formation (the Party for Justice and Development) that participates to the political life of the country. It is allowed to participate because it is a party able to compromise with the regime and can be co-opted. For instance, upon request by the authorities, the party decided not to run candidates in all constituencies at the 2003 local elections precisely to avoid sweeping the board and embarrassing the King with a significant Islamist electoral victory. Secondly, there is the 'barely tolerated" and very popular Justice and Charity Association founded by the long time dissident Sheikh Abd al-Salam Yassine. This association operates like a social movement providing services and assistance to the poorer sections of society and is preoccupied with Islamising society from below. This does not mean that the association does not have a political line. The Sheikh is very outspoken in his criticism of the Crown, which is blamed for the ills of Moroccan society (poverty, corruption of moral values, deference to the West, social atomisation) and Islam is pointed out as the solution to all these difficulties. ${ }^{57}$ Finally, there is the clandestine Salafist Jihad, a group devoted to overthrowing the government through violence. It is a minoritarian strand and does not enjoy the overt nor covert support of the other groups examined.

The emergence of Islamism as a tool of political opposition in Morocco challenges the conventional wisdom about the King's religious legitimacy. The King enjoys this legitimacy as a direct descendent of the Prophet, but this is not sufficient to halt the spreading of Islam as a vehicle for political opposition because the movements using it have real economic, political and social grievances to build their support on. There are three different sets of influences that contributed to the rise of political Islam in Morocco. First of all, the failure of ideologies imported from the West combined with perceived great Islamic victories against powerful enemies (i.e. the Shah in Iran) contributed to make Islam a very popular ideological tool. Islam as the solution began to be the slogan also given the Iranian revolution, the Soviet defeat in Afghanistan by an Islamic guerrilla and the Palestinian Intifada. All these events touched Morocco only very marginally, but contributed to create an ideological climate favourable to Islamist movements, which were also busy providing much needed services to the population. ${ }^{58}$ Exchanges of ideas can have a very significant effect in international politics. ${ }^{59}$ Secondly, 
the Gulf crisis and subsequent war of 1991 contributed to make Islamic movements a serious player on the Moroccan political scene. The vast majority of the population was not necessarily sympathetic to Saddam Hussein, but the crisis served to highlight the double standards of the West when dealing with the Arab world. Given that King Hassan II had committed the country to support the US-led coalition, popular opposition to the war gave the Islamists a considerable boost to raise their political profile. Finally, the neo-liberal economic policies forced on the Morocco contributed to the strengthening of the Islamist movements. The economic and social costs of such reforms are enormous and entailed the emergence of a small class of nouveaux riches, while the vast majority of the population struggles to survive. ${ }^{60}$ Capitalising on the negative effects of such reforms, the Islamist movement can play the social justice card. Sheikh Yassine in particular is very vocal on this point and he is very much concerned with the international environment and the constraints that derive from it when it comes to the choices that Morocco faces.

When analysing the reasons for the failure of the process of democratisation to consolidate, the role of international factors is very relevant. Whereby similar processes in Latin America, Eastern Europe, East Asia have been supported by the leading actors in the international system, democratisation in the Arab world is instead treated with much suspicion because of the nature of the 'unreasonable' Islamist opposition. Gambill argues for instance that 'the proposition that authoritarianism in the Arab world is sustained by the absence or weakness of external forces ${ }^{31}$ should be examined further and he affirms that such a factor is decisive in explaining the Arab democracy deficit. In the case of Morocco, the attitude of the United States, France and to a lesser extent the European Union is the external variable that stifled consolidation. The main driving force behind the behaviour of these actors has been the necessity to ensure regional stability, which, they argue, would be compromised by the arrival to power of an Islamist movement. It is for this reason that they generally tend to support more secular parties that, however, do not enjoy great popular support or are often co-opted by the regime, therefore losing much of their oppositional nature.

The end of the Cold War seemed to usher in a new era: the age of liberalism would finally dawn on international politics. It was believed that liberal-democracy 
would spread across the globe and the UN would become the forum where international disputes would be settled and where actions in breach of international law would be condemned and punished. This enthusiasm did not last very long and the West became soon preoccupied with the rise of political Islam, which carried a revolutionary message and questioned the status quo of the international system. ${ }^{62}$ The 1991 Gulf War showed to western countries how little support and credibility they actually enjoyed in the Arab world and made them realise that they were increasingly dependent on authoritarian leaders in the region to maintain the stability necessary to continue extracting benefits. There is very little doubt that the fear of an Islamist party coming to power through free and fair elections drove policies in the 1990s and well into the new century. Such an attitude towards Islamist movements is not dictated, although it is justified, by a principled policy of defending democracy and human rights. Rather, it is dictated by the necessity to avoid having a party in power that would question the fundamental tenets upon which the current international system is built on. Thus, the provision of political legitimacy in international forums, the granting of credits and loans to keep the economy afloat and the sale of arms to counter any militant resistance are all instruments used to support the Moroccan Kingdom. No serious attempt has been made to effectively promote democratic change either through carrots or sticks. In turn, such support considerably lowers the costs of repression of the Moroccan ruling elites. A few examples suffice to demonstrate this. The recent war on terror has helped Morocco to justify its repressive and authoritarian policies with the blessing of the US government, who just signed a free-trade agreement with Morocco, which does not include any conditionality in terms of political reforms. France also cancelled a portion of Morocco's debt during the King's visit to Paris in $2000 .{ }^{63}$ While all these measures could be potentially used to put pressure on the regime to engage in serious political reforms, they end up be functioning as support for the status quo. No widespread international condemnation of Morocco has been issued following the publication of the recent Amnesty International report detailing the repressive practices of the regime. ${ }^{64}$ Finally, military cooperation with NATO gives Morocco both international legitimacy and contacts with European and American counterparts. In a country where socio-economic indicators are very poor, military expenses represent 2.3 billion US dollars in $2003 .{ }^{65}$ 
How important are these external factors in stalling democratisation? It is quite difficult to assess the relative importance of the external over the internal because the two cannot be easily separated and measured. However, it is the case that the external environment is not conducive to full democratisation because of the nature of the opposition. Thus, domestic ruling elites and international actors interact in a complex game to support each other to the detriment of electoral democracy.

\section{Conclusion}

International factors are an important part of the story of transitions and they should be incorporated in the analysis of such processes. The case of Morocco shows that there are external-internal linkages that need to be examined to understand its stalled democratisation. However, strong causal mechanisms are extremely difficult to prove and this probably explains the prevalent focus on domestic politics and choices. In spite of this, the Moroccan case indicates that weak causal inferences can be made. The theoretical framework proposed emphasises the role of agency over structure and there is evidence to suggest that internal-external linkages determine the path of the transition through interaction.

Regarding Morocco, while the 1983 decision to open up the political system was based on an autonomous domestic decision-making process, the subsequent development of the transition and its failed consolidation are influenced by the external environment. This is particularly evident when we analyse the nature of the opposition. There is very little doubt that international factors helped the Islamist movement grow even in a country that had been previously thought immune from such phenomenon. ${ }^{66}$ Also, there is very little doubt that it is precisely the emergence of such movement that lowered the costs of repression in light of the attitudes of countries and organisations. The costs have been lowered to such an extent that authoritarianism is being rewarded for keeping the Islamist movement out of power. This is done through economic incentives, absence of conditionality, support for weak secular parties, military aid and international legitimacy.

In terms of the literature on democratisation, it emerges that the external intervention to change the cost and benefit analysis of the domestic actors is not always intended to support democracy. At times it is intended to stifle it. In terms of international 
relations literature, it is worth noting that peace and stability are not necessarily achieved through the spread of democracy or liberal values. Quite the opposite is in fact true if we take the case of Morocco on board. The use of realist concepts can account for the antidemocratic impact of foreign policies towards Morocco. The stalled democratisation of country cannot be solely laid at the door of the international community, but the actions undertaken by external actors have strengthened the current regime with their focus on economic openness and façade democratic elections. The nature of the opposition seems to worry more than the authoritarian nature of the current ruler. This view is well summarised by Zakaria, who argues that: 'the Arab rulers of the Middle East are autocratic, corrupt, and heavy-handed. But they are still more liberal, tolerant, and pluralistic than those who would likely replace them. ${ }^{, 67}$ As long as this remains the perception at policy-making level, the international context is likely to continue to support authoritarianism or 'controlled' democracy.

${ }^{1}$ Guillermo O'Donnell, Philippe Schmitter and Laurence Whitehead (eds.) Transitions from Authoritarian Rule (Baltimore: The Johns Hopkins University Press, 1987).

2 Jean Grugel, 'Democratisation studies and globalisation: the coming of age of a paradigm', British Journal of Politics and International Relations, Vol. 5, No. 2, (2003), p.258.

${ }^{3}$ Samuel Huntington, The Third Wave. Democratization in the Late Twentieth Century (Norman: University of Oklahoma Press, 1991).

4 Laurence Whitehead, 'Three International dimensions of Democratization' in Laurence Whitehead (ed.) The International Dimensions of Democratization (New York: Oxford University Press, 1996).

5 Jeff Haynes, 'Comparative Politics and Globalisation', European Political Science, Vol. 2, No. 3, (2003), pp. 17-26.

${ }^{6}$ Daniel Brumberg, 'Liberalisation versus Democracy: Understanding Arab Political Reform', Working Papers, Carnegie Endowment for International Peace, (2003), p. 3.

${ }^{7}$ Ibid., p. 3.

8 Darren Hawkins, 'Democratisation Theory and Nontransitions: Insights from Cuba', Comparative Politics, Vol. 34, No. 4, (2001), pp. 441-461.

${ }^{9}$ Gary King,, Robert Keohane and Sidney Verba Designing Social Inquiry. Scientific Inference in Qualitative Research (Princeton: Princeton University Press, 1994).

${ }_{10}$ Bent Flyvberg, Making Social Science Matter. Why Social Inquiry Fails and How it Can Succeed Again (Cambridge: Cambridge University Press, 2001).

${ }^{11}$ Philippe Schmitter, 'The Influence of the International Context Upon the Choice of national Institutions and Policies in New Democracies' in Laurence Whitehead (ed.) The International Dimensions of Democratization (New York: Oxford University Press, 1996), p. 27.

${ }^{12}$ Hakan Yilmaz, 'External-Internal Linkages in Democratization: Developing an Open Model of Democratic Change', Democratization, Vol. 9, No. 2, (2002), p. 68.

${ }^{13}$ Richard Sakwa, 'Introduction. The Democratic Experience' in Richard Sakwa (ed.) The Experience of Democratisation in Eastern Europe (London: Macmillan Press, 1999). 
${ }^{14}$ Geoffrey Pridham, The Dynamics of Democratisation, (London: Continuum, 2000).

${ }^{15}$ Yilmaz, pp. 67-84.

16 Richard Gillespie and Richard Youngs, 'Themes in European Democracy Promotion', Democratization, Vol. 9, No. 1 (2002), pp. 1-16.

${ }^{17}$ Francesco Cavatorta, 'The Failed Liberalisation of Algeria and the International Context: A Legacy of Stable Authoritarianism', Journal of North African Studies, Vol. 7, No. 4, (2002), pp. 23-43.

18 Mustafa Hamarneh, 'Democratisation in the Mashreq: the Role of External Factors', Mediterranean Politics, Vol. 5, No. 1, (2001), p. 77.

${ }^{19}$ Yilmaz, p. 87.

${ }^{20}$ Michael Cox, 'Rebels Without a Cause? Radical Theorists and the World System after the Cold War', New Political Economy, Vol. 3, No. 3, (1998), pp. 445-460.

${ }^{21}$ Kenneth Waltz, Theory of International Politics (London: Addison-Wesley, 1979).

${ }^{22}$ Robert Chase, Emily Hill and Paul Kennedy, 'Pivotal States and US Strategy', Foreign Affairs, Vol. 75, No. 1, (1996), p. 33.

${ }^{23}$ For an example of such an influence see Lounis Aggoun and Jean-Baptiste Rivoire, Françalgérie. Crimes et Mensonges d'Etats (Paris: La Découverte, 2004).

${ }^{24}$ Quandt, William, Between Ballots and Bullets (Washington DC: Brookings Institute Press, 1998).

${ }^{25}$ Philippe Schmitter and Terry Lynn Karl, 'What Democracy Is...and Is Not', Journal of Democracy, Vol. 2, No. 1, (1991), pp. 75-88.

${ }^{26}$ Sheri Berman, 'Islamism, Revolution and Civil Society', Perspectives on Politics, Vol. 1, No. 2, (2003), pp. 257-272.

${ }^{27}$ Tim Dunne and Brian Schmidt, 'Realism' in John Baylis and Steve Smith, The Globalization of World Politics, (Oxford: OUP, 2001).

${ }^{28}$ Rémy Leveau, 'Morocco at the Crossroads', Mediterranean Politics, Vol. 2, No. 2 (1997), p. 95

${ }^{29}$ Marvine Howe, 'Fresh Start for Morocco', Middle East Policy, Vol. 8, No. 2 (2001), p. 59.

${ }^{30}$ Ibid., p. 60.

${ }^{31}$ For an overview of the relationship between Morocco and Israel see, 'Le Maroc et le Mossad', Le Journal Hebdomadaire, No. 167, July 2004, pp. 20-29.

${ }^{32}$ Abdeslam Maghraoui, 'Depoliticisation in Morocco', Journal of Democracy, Vol. 13, No. 4 (2002), p. 26.

${ }^{33}$ Abdellatif Moutadayene, 'Economic Crises and Democratisation in Morocco', Journal of North African Studies, Vol. 6, No. 3 (2001), p. 74

${ }^{34}$ Michael Willis, 'After Hassan: A New Monarch in Morocco', Mediterranean Politics, Vol. 4, No. 3 (1999), p. 218.

${ }^{35}$ Thierry Desrues and Eduardo Moyano, 'Social Change and Political Transition in Morocco', Mediterranean Politics, Vol. 6, No. 1 (2001), p. 40.

${ }^{36}$ Ibid., p. 41.

${ }^{37}$ John Entelis, 'Un Courant Populaire Mis à l'Ecart', Le Monde Diplomatique, No. 589 (2002), p. 22.

${ }^{38}$ Maghraoui, p. 30.

${ }^{39}$ Moutadayene, p. 72.

${ }^{40}$ Moutadayene, p. 72.

${ }^{41}$ Azzedine Layachi, 'Reform and the Politics of Inclusion in the Maghreb', Journal of North African Studies, Vol. 5, No. 3 (2000), p. 25.

${ }^{42}$ Ibid., p. 26.

${ }^{43}$ Tom Najem, 'Privatisation and the State in Morocco: Nominal Objectives and Problematic Realities', Mediterranean Politics, Vol. 6, No. 2 (2001), p. 51. 
${ }^{44}$ See Tom Pierre Najem, 'State Power and Democratization in North Africa: Developments in Morocco, Algeria, Tunisia and Libya' in Amin Saikal and Albrecht Schnabel (eds.) Democratization in the Middle East (New York: United Nations University Press, 2003), p. 187.

${ }^{45}$ Ibid., p. 188.

${ }^{46}$ Michelle Charasse, Bilan de la cooperation avec les Etats du Maghreb: une 'rénovation' justifiée, Commission des Finances du Sénat, No. 83, Paris, France, 2000-2001.

${ }^{47}$ For the details of the friendly relations between France and Morocco, see Jean-Pierre Tuquoi, Le Dernier Roi. Crépuscule d'une Dynastie (Paris: Bernard Grasset, 2001)

${ }^{48}$ Isabel Romeo, "The European Union and North Africa: Keeping the Mediterranean "Safe" for Europe', Mediterranean Politics, Vol. 3, No. 2 (1998), p. 22.

49 Richard Youngs, 'European Approaches to Security in the Mediterranean', Middle East Journal, Vol. 57 (2003), pp. 414-431.

${ }^{50}$ Richard Gillespie, 'Spain and the Western Mediterranean', Working Paper 37/01, ESRC Programme, Sussex University, 2001. Available at http://www.oneeurope.ac.uk/pdf/w37gillespie.pdf. Accessed on 1/03/2005.

${ }^{51}$ Pierre Vermeren, Le Maroc en transition (Paris : La Découverte, 2002), pp. 222-223.

${ }^{52}$ Gilles Perrault, Notre Ami le Roi, (Paris: Gallimard, 1990).

${ }^{53}$ Aboubakr Jamai, 'Dérive Autoritaire du Gouvernment Marocain', Le Monde Diplomatique, No. 562 (2001), p. 8.

${ }^{54}$ Anoushiravan Ehteshami, 'Islam, Muslim Polities and Democracy', Democratization, Vol. 11, No. 4 (2004), p. 102.

${ }^{55}$ Michael Laskier, 'A Difficult Inheritance: Moroccan Society under King Mohhamed VI', Middle East Review of International Affairs, Vol. 7, No. 3 (2003), p. 4

${ }^{56}$ Ibid., p. 4.

${ }^{57}$ See what can be considered the association and Yassine's political manifesto at http://www.yassine.net//lettres/memorandum.htm. Accessed on 22/7/2003.

${ }^{58}$ Mustapha Kamal Pasha, 'Globalisation, Islam and Resistance', in Barry Gills (ed.) Globalisation and the Politics of Resistance (Basingstoke: Palgrave, 2000), p. 250.

${ }^{59}$ Jeffrey Haynes, 'Transnational Religious Actors and International Politics', Third World Quarterly, Vol. 22, No. 2 (2001), pp. 143-158.

${ }^{60}$ Z. Daoud, 'L'Alternance à l'Epreuve des Faits', Le Monde Diplomatque, No. 541 (1999), p. 29.

${ }^{61}$ Gary Gambill, 'Explaining the Arab Democracy Deficit, Part II: American Policy', Middle East Intelligence Bullettin, Vol. 5, No. 8-9 (2003), p. 1.

${ }^{62}$ Michael Salla, 'Political Islam and the West: a New Cold War or Convergence?', Third World Quarterly, Vol. 18, No. 4 (1997), pp. 729-742.

${ }_{63}$ Tuquoi, p.

${ }^{64}$ See 'Amnesty, le rapport qui accable', Le Journal Hebdomadaire, No. 166, July 2004, pp.2029.

${ }^{65}$ See 'L'Armée: le grand tabou', Le Journal Hebdomadaire, No. 194, February 2005, pp. 18-27.

${ }^{66}$ Henry Munson Junior, 'Morocco's Fundamentalists', Government and Opposition, Vol. 26, No. 3 (1991), pp. 331-344.

${ }^{67}$ Fareed Zakaria, 'Islam, Democracy and Constitutional Liberalism', Political Science Quarterly, Vol. 119, No. 1 (2004), p. 2. 